\title{
第26回総会シンポジゥムII
}

\section{III. 広サイズフィルムの水洗乾燥の諸問題}

金沢大学医学部付属病院中央放射線部（部長 平松 博 技師長 松田憲司）

南純次

協力者水島隆

\section{は じ め}

1944年米国パコ社に扑いて最初のX線フィルムの自働 現像装置が発表され以来25年を経た今日その改良普及は 実にめざましく，わが国において最近数年間に設置する 病院が急激住加している。

本院放射線部に扔いてもX線フィルムの現像処理の自 働迅速化を考へ，1964年 8 月国産さくらXレイ自働現像 装置 I 型 2 台を購入 ( 8 分処理) 設置し，使用していた が, その後撮影枚数の増加により, なお一層の処理の迅 速化が要求されるようになり，1968年12月それらの装犆 を処理洔間 3 分 30 秒汇短縮改良し，現在にいたっている.

自㗢見像装置の特長は今更いうまですなく自働仕上が りの一定均一化であるが近代医学の発達にとあなって, 処理の迅速化がなお一そう大きく取り上げら礼今日では 90秒処理装置が開発市販されるようになってきた.

また处理の迅速と同時に近年その使用されるXレイフ イルムも次第に大型サイズが用いられるようになり，し か屯近年連続撮影装置の出現によって更に大量処理が要 求されるようになった。

今回筆者等は大型サイズフィルムの迅速処理㧍よびそ の枚数増加によって生ずる, 仕上がり状態を大角フィル 么 $(356 \mathrm{~mm} \times 356 \mathrm{~mm})$ を対称に，1. 水洗流水量之温度, 2. 乾燥温度と風量, 3. 湿度と乾燥. 以上 3 点の諸条件に 対して検討を試みたので以下報告する.

\section{目的および方法}

主として連続撮影による大角フィルム $(356 \mathrm{~mm} \times 356$ $\mathrm{mm})$ を対称に, 水洗流水量と温度, および乾燥温度と 風量ならびに湿度と乾燥，の問題に対して実験を加えた のである.

方法としてはさくら自働現像装置 3 分30秒改良型を用 いた．本装置の口ーラによるフィルム速度は公称 $90 \mathrm{~cm} / \min$ である.
な打各サイズのフィルム移動速度は次の通りである. これは各サイズフィルムの完了移動を実測で示したもの で，必ず計算值とは一致せず，ローラーのひずみによる フィルム压着不良によって生ずるフィルムのスリップが 主なる原因と思われる。

\begin{tabular}{lllll}
\multicolumn{5}{c}{ フィルム完全移行時間 } \\
& 現像 & 定着 & 水洗 & 乾燥 \\
半切 & 72 秒 & 同左 & 同左 & 80 秒 \\
大陸 & 64 秒 & 同左 & 同左 & 75 秒 \\
四切 & 61 秒 & 同左 & 同左 & 699 秒 \\
& 57秒 & 同左 & 同左 & 65 秒 \\
六切 & 55 秒 & 同左 & 同左 & 63 秒
\end{tabular}

水洗状態は流水量ならびに温度について検討し，その 評価は流水中の八イポ量で行ないこれはフィルム処理中 における水洗後の流水 $1 l$ 中に含まれるハイポ含有量を調 べたのである.

水洗状態の試験法については，大規，前田，坂口氏等 による比色法によるフィルム残留八イポの測定，または 最近発表された，コダックのB. Hutichurs 氏の，アセ トアミド法, および硫化銀法, 硝酸銀法等数多くの試験 があるが筡者等は従来より行なわれている、ヨード滴定 法によって検討した。

水質についてはフィルムの仕上がりに対してフィルム の経年変化等に多少の影響があるようであるがてれに関 しては Kodak, Medical Radiography に詳細に報告さ れている. 本院の水質は調查の結果次の通りであった.
1. 過マンガン酸カリ $1.7 \mathrm{ppm}$
2. 塭素 $11.2 \mathrm{ppm}$
3. 鉄分 $0.1 \mathrm{ppm}$
4. $\mathrm{pH}$ 值 7.5

以上の調査報告があった。

フィルム仕上がりの状態は主として，フィルムの重量 の測定によったのであるが，乙の場合にはサートリウス

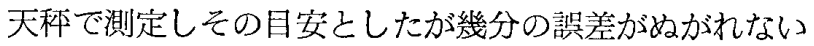


ので平均值で示した。

定着液の疲学性については $\mathrm{pH}$ 值を以って表わしたが, フィルムの硬膜性は压力試験，およびスリキズ試験は特 に行なわなかった。

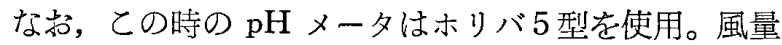
変化および乾燥温度はアネモマスター風力計を用いて測 定し特に風量変化については本装置のエアーブロアーの 口径を変え, 各フィルムの乾燥時における状態を平均值 で示した。

濃度計はさくら RD-2R 型を使用して仕がり状態のば らつき濃度曲線で示したが，その識別には多小判定が困 難なすのが見られたが肉跟で見た状態を併用してそれを 矢印で示した。

湿度については主として当地の気象台に依頼して測定 を行なったがなお湿球温度計によってす測定し各々の平 均值で示した。

\section{考察}

\section{水洗流水量とハイポ検出量の関係}

この問題に関しては筆者等は昭和35年札幌総会におい て発表報告し，また紐江氏等の報告もあるが，自動現像 装置では極わめて短時間内に水洗が要求されるので給水 管理は決して無視できない，したがって水洗效果は水の 流量, 温度に非常に影響され易く，水洗温度が高い程水 洗効率が良くなるが水洗槽内の含有八イポ量むまたフイ ルム処理枚数の増大によって多くなってくることが当然 である.

そこで水洗水の流量を変化させとの状態を観察した。

大角20枚処理（図 1，表 1）

今大角20枚処理について見るに図 1 亿示す如く水洗流

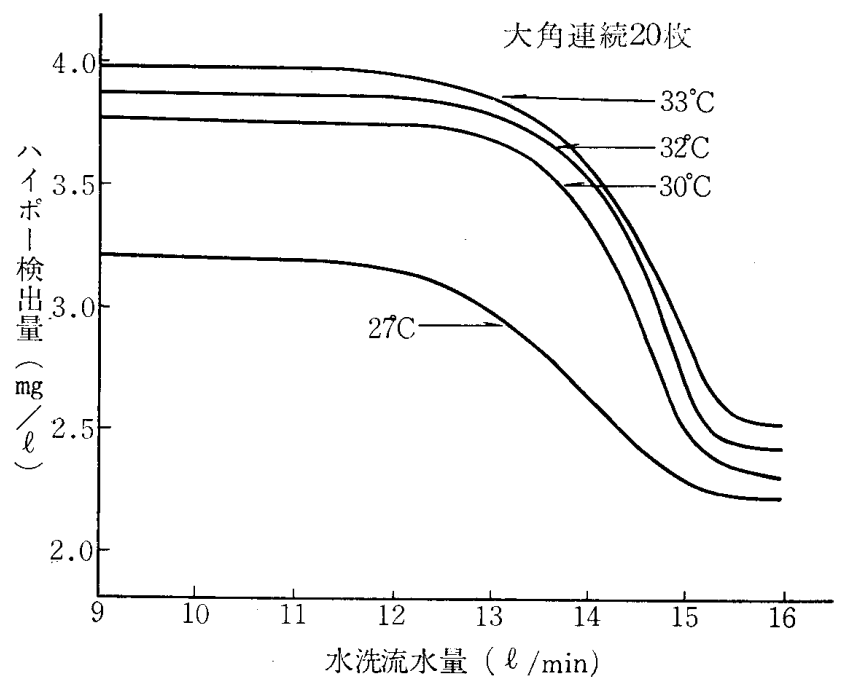

図 I 水洗流水量と八イポ検出量の関係
水量 $13 \mathrm{l} / \mathrm{min}$ では温度 $27^{\circ} \mathrm{C}$ では八イポ検出量が 2.65 $\mathrm{mg}$ と底く $30^{\circ} \mathrm{C}$ では $3.16 \mathrm{mg} 33^{\circ} \mathrm{C}$ で $3.3 \mathrm{mg}$ を示し次第

表１水洗流水量とハイポ検出量の関係

\begin{tabular}{|c|c|c|c|c|c|c|c|}
\hline \multirow{2}{*}{$\begin{array}{l}\text { 水洗 } \\
\text { 温度 }\end{array}$} & \multicolumn{3}{|c|}{ 水 洗 } & \multicolumn{3}{|c|}{ 水 量 $(l / \mathrm{min})$} & \multirow[b]{2}{*}{15} \\
\hline & 9 & 10 & 11 & 12 & 13 & 14 & \\
\hline $27^{\circ} \mathrm{C}$ & 3.15 & 3.12 & 3.08 & 2.95 & 2.66 & 2.24 & 1.95 \\
\hline $30 "$ & 3.59 & 3.55 & 3.48 & 3.34 & 3.00 & 2.35 & 2.02 \\
\hline $32 "$ & 3.75 & 3.74 & 3.70 & 3.56 & 3.14 & 2.43 & 2.06 \\
\hline $33 "$ & 3.83 & 3.82 & 3.78 & 3.65 & 3.30 & 2.60 & 2.10 \\
\hline
\end{tabular}

にハイポ含有が多くなってきている.

\section{同じく40枚処理(図 2, 表 2)}

については $27^{\circ} \mathrm{C} て ゙ ~ 2.9 \mathrm{mg}, 30^{\circ} \mathrm{C}$ では $3.66 \mathrm{mg}$ となってい る. すなわち同一流水量です水洗温度の変化によって水洗 效率が大きく違って来ている.

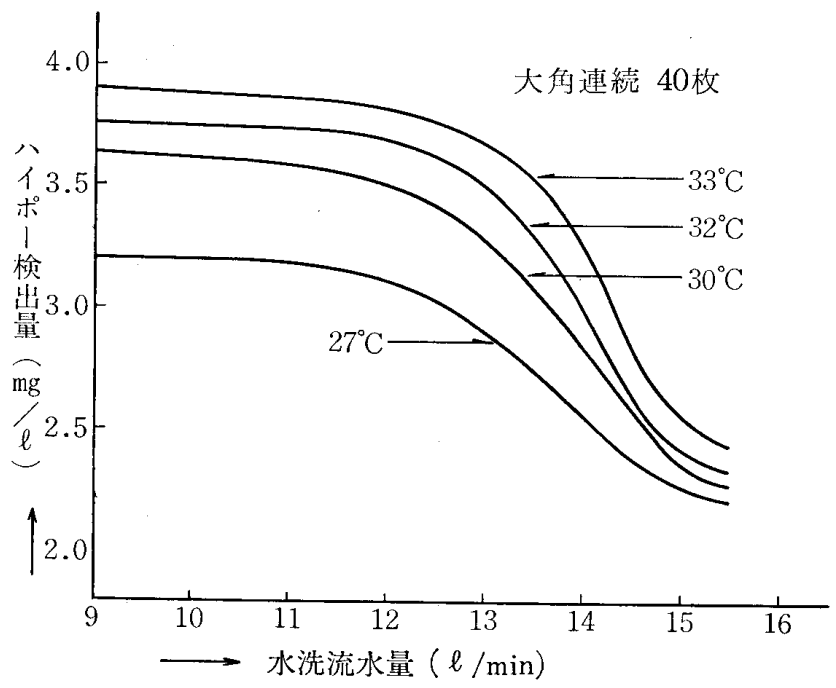

図 2 水洗流水量と八イポ検出量の関係

表 2 水洗流水量とハイポ検出量の関係

\begin{tabular}{|c|c|c|c|c|c|c|c|}
\hline \multirow{2}{*}{$\begin{array}{l}\text { 水洗 } \\
\text { 温度 }\end{array}$} & \multicolumn{7}{|c|}{ 水 洗 流 水 量 $(l / \mathrm{min})$} \\
\hline & 9 & 10 & 11 & 12 & 13 & 14 & 15 \\
\hline $7^{\circ} \mathrm{C}$ & 3.20 & 3.20 & 3.18 & 3.10 & 2.90 & 2.56 & 2.26 \\
\hline 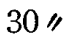 & 3.63 & 3.60 & 3.58 & 3.50 & 3.26 & 2.83 & 2.36 \\
\hline 2 & 3.76 & 3.74 & 3.73 & 3.68 & 3.50 & 2.98 & 2.43 \\
\hline & 3.90 & 3.86 & 3.85 & 3.80 & 3.66 & 3.23 & 2.55 \\
\hline
\end{tabular}

60枚処理（図 3，表 3）

60 枚好理を見ると図で示す如く同じく流水量 $13 l / \mathrm{min}$ で水洗温度 $27^{\circ} \mathrm{C}$ で $30 \mathrm{mg}, 30^{\circ} \mathrm{C}, 3.7 \mathrm{mg}, 33^{\circ} \mathrm{C}$ では実に $40 \mathrm{mg}$ 近くを示し, フィルム処理枚数の増加にしたがっ て同一条件であ急激に八イポ含有量が増えてきている. 水洗流水量を増すととは水洗槽内の八イポ含有量を 


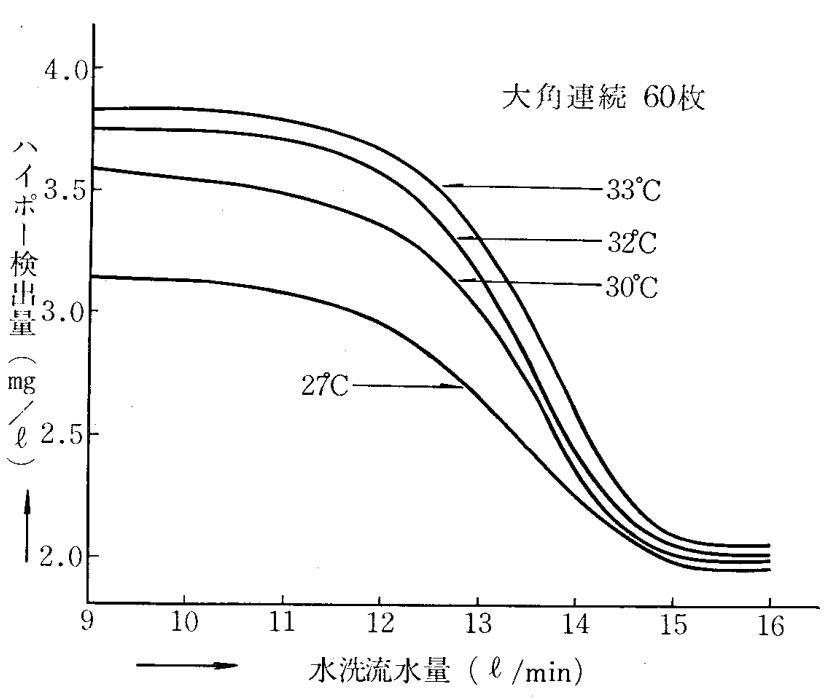

図 3 水洗流水量と八イポ検出量の関係

表 3 水洗流水量とハイポー検出の関係

\begin{tabular}{|c|c|c|c|c|c|c|c|}
\hline \multirow{2}{*}{$\begin{array}{l}\text { 水洗 } \\
\text { 温度 }\end{array}$} & \multicolumn{3}{|c|}{ 水 洗 流 } & \multicolumn{3}{|c|}{$(l / \min )$} & \\
\hline & 9 & 10 & 11 & 12 & 13 & 14 & 15 \\
\hline $27^{\circ} \mathrm{C}$ & 3.22 & 3.20 & 3.20 & 3.16 & 3.00 & 2. 64 & 2.30 \\
\hline $30 "$ & 3.78 & 3.78 & 3.75 & 3.74 & 3.69 & 3.36 & 2.50 \\
\hline $32 "$ & 3.88 & 3.88 & 3.88 & 3.86 & 3.80 & 3.54 & 2.70 \\
\hline $33 "$ & 3.98 & 3.98 & 3.98 & 3.95 & 3.86 & 3.59 & 2.90 \\
\hline
\end{tabular}

減らすのに大きく関与するが是認されている. $13 l / \mathrm{min}$ から $14 \mathrm{l} / \mathrm{min}$ 前後ではまだ不足と考える.

な挍60枚処理では $13 l / \mathrm{min}$ 以下の流水量で水の温度 $33^{\circ} \mathrm{C}$ 付近でハイポ污染による仕がりむらを認めた。乙れ は明らが流水中の含有ハイポがローラを污染したすの と推定するる.

また水洗温度 $27^{\circ} \mathrm{C}$ の場合であるが，乙れは低温による 水洗効率が悪く流水量を増してもその変動差は少なく乾 燥障害を認好た。 図 4 参照.

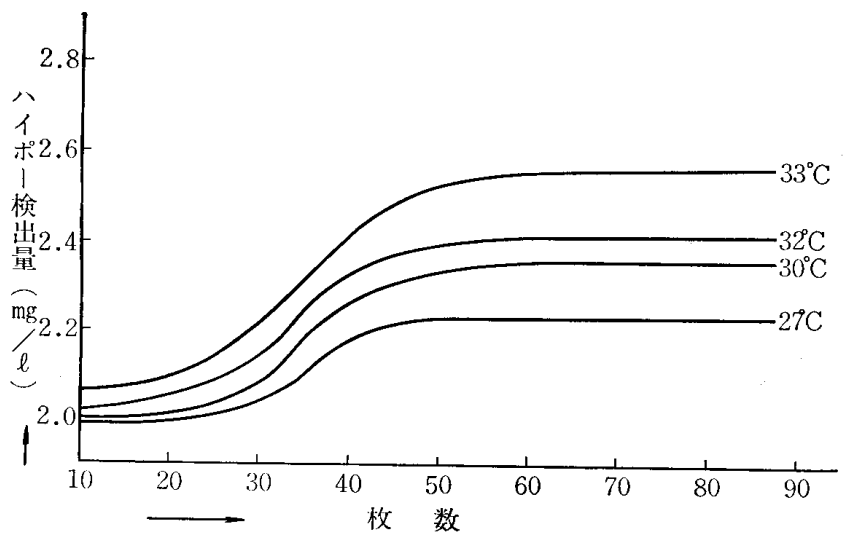

図 4 水洗温度と処理枚数
毎分の水洗流水量を増すととは水洗槽内の含有八イポ を減らすととに大きく関与するが，今日盛んに行なわれ ている広サイズフィルムによる連続処理時には指定され ている流量では不足であると考える.

\section{水洗温度と処理枚数 図 4, 図 5 , 表 4}

筆者等は水洗が一定值をたどる状態を主として温度と 処理枚数の増加によって生ずる変化を検討した．同一流

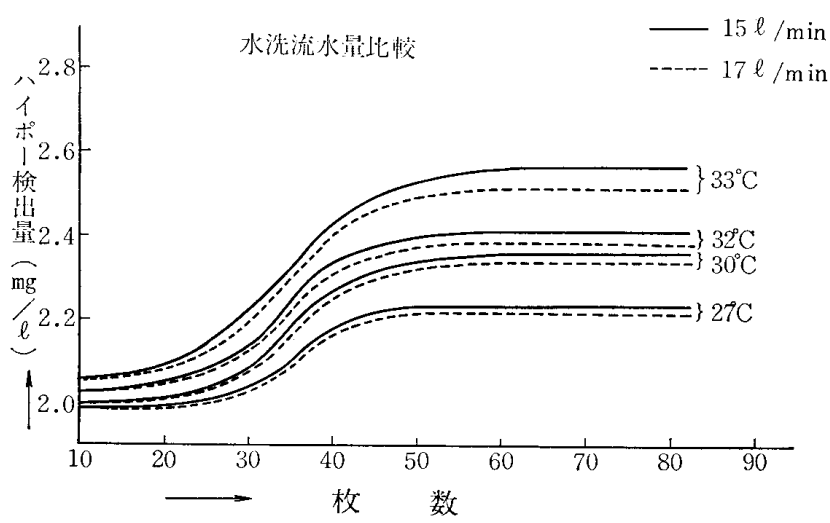

図 5 水洗温度之処理枚数

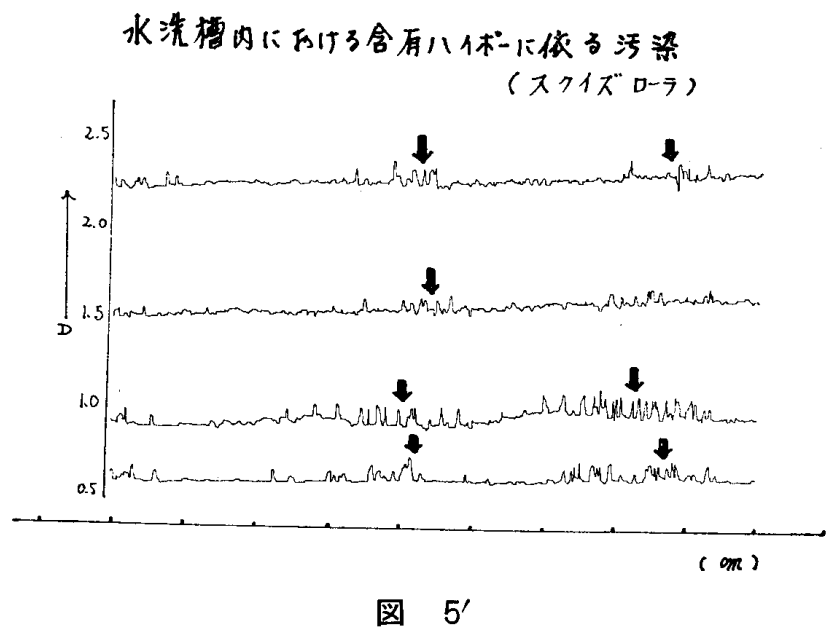

表 4 水洗温度之処理枚数

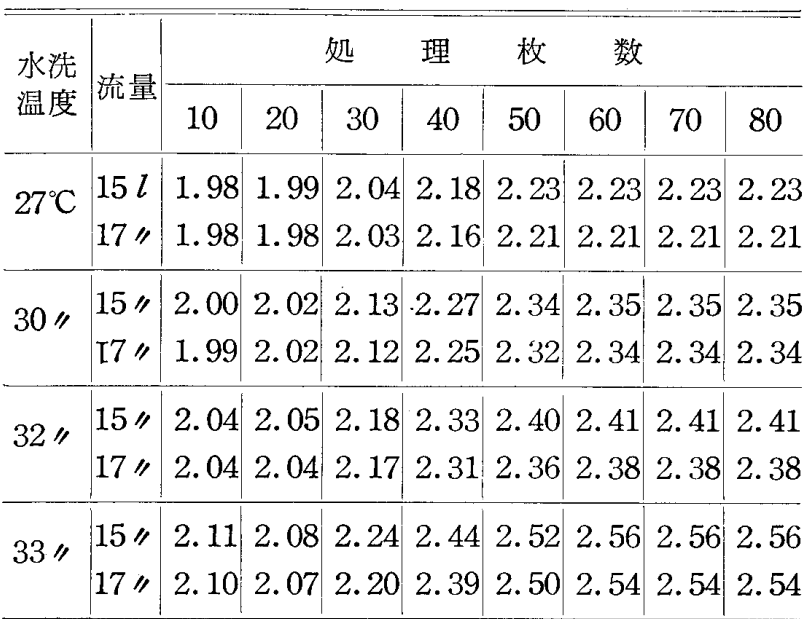


水量であ温度の変化によって大きく差が生じている，乙 れは明らかに温度による水洗效率現象であるが，図に示

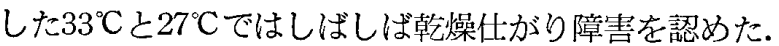

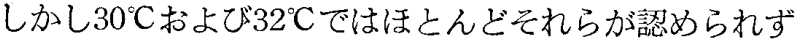
図の曲線上では相接近し平行をたどっている.

そこでとの問題を水洗流量 $15 \mathrm{l} / \mathrm{min}$ と $17 \mathrm{l} / \mathrm{min}$ で比

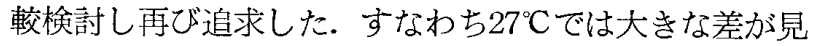
られないが， $30^{\circ} \mathrm{C}$ から $33^{\circ} \mathrm{C}$ と温度が高くなるにしたがっ

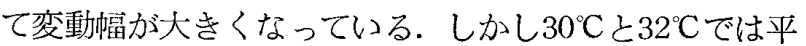
行幅が少なく $33^{\circ} \mathrm{Cでは} 0.5 \mathrm{mg}$ と開いている。 また $27^{\circ} \mathrm{C}$ では温度が低いために流量が増してもほとんど変化が喼 められなかった，水洗効率か低いとと示している。

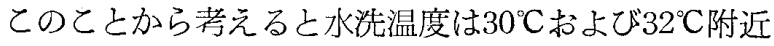
が適当と考えられ，水洗流水量は $15 \mathrm{l} / \mathrm{min}$ です充分で はないかと思われる。

\section{定着補充睤と処理フィルム枚数增加に伴う定着液 $\mathrm{pH}$} 值の変動（図 6, 図6')

定着液の疲労はフィルムの水洗乾燥仕がりに大きく影 響するが，その測定法は種々あるが筆者等従来からの方 法である $\mathrm{pH}$ 值を以って疲労度の目安とした。

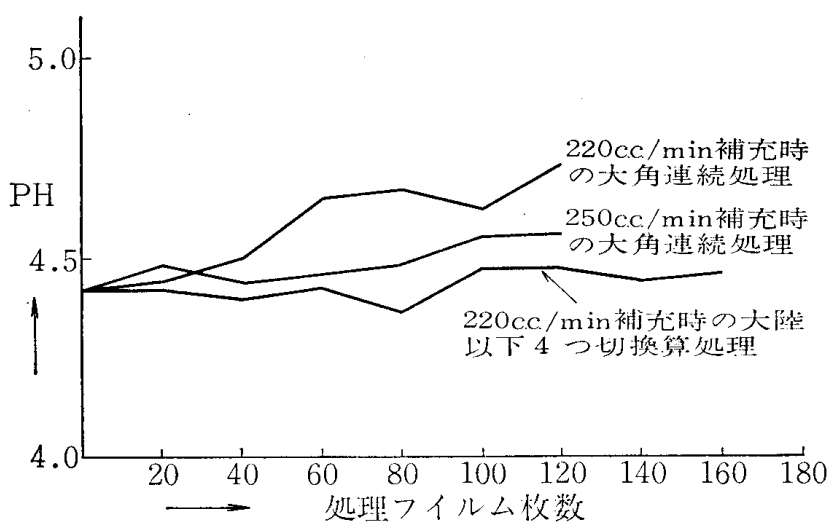

図 6 定着液補充量と処理フィルム枚数増加に伴なう定着液

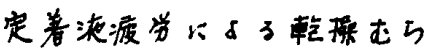

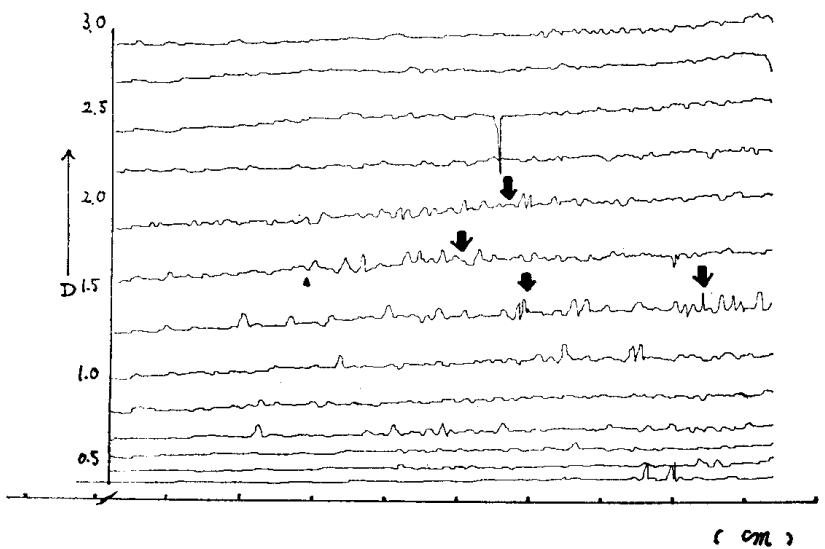

図 $6^{\prime}$
大角連続処理で図に示す補充量 $220 \mathrm{cc} / \mathrm{min}$ を見ると 60枚までは急速に上昇し $\mathrm{pH}$ 值は 4.65を示し100枚加ら 再び上昇を始めている.

$250 \mathrm{cc} / \mathrm{min}$ では曲線は比較的に安定度を保ち徐々に 上昇している.

大陸以下四ッ切の場合では補充量 $220 \mathrm{cc} / \mathrm{min}$ ではほ とんど大きな変動は見られなかった，以上のととから考 えると大角以上の大型フィルムの連続処理時には補充量 $250 \mathrm{cc} / \mathrm{min}$ でも決して充分とは考えられず，100枚以上 処理の場合で $300 \mathrm{cc} / \mathrm{min}$ 近く必要とされると思う。し かしての問題に関しては使用フィルムの乳剤特性，また は使用される定着液組成に関係すると思われるのでさら に，検討の必要があると思う。乙の㬰験では定着淮温度 $322^{\circ} \mathrm{C}$ である。

\section{風量と水洗温度および乾燥の関係（図 7)}

水洗流水量を $15 \mathrm{l} / \mathrm{min}$ に対して水の温度を $27^{\circ} \mathrm{C}, 30$ ${ }^{\circ} \mathrm{C}, 33^{\circ} \mathrm{C}$ の各温度に変えそれに対して風量を変化させ て乾燥状態を検討した． $33^{\circ} \mathrm{C}$ では曲線は他の線よりもゅ

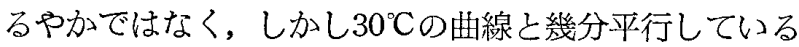
けれどあ乾燥にさいして風量が異なっている $27^{\circ} \mathrm{C} は$ 他の 曲線よりも平行的でなく食量 $7 \mathrm{~m}^{3} / \mathrm{min}$ でも充分な乾燥 状態とはいえず，水洗効率が乾燥に対しても大きく影響 すると思われる。

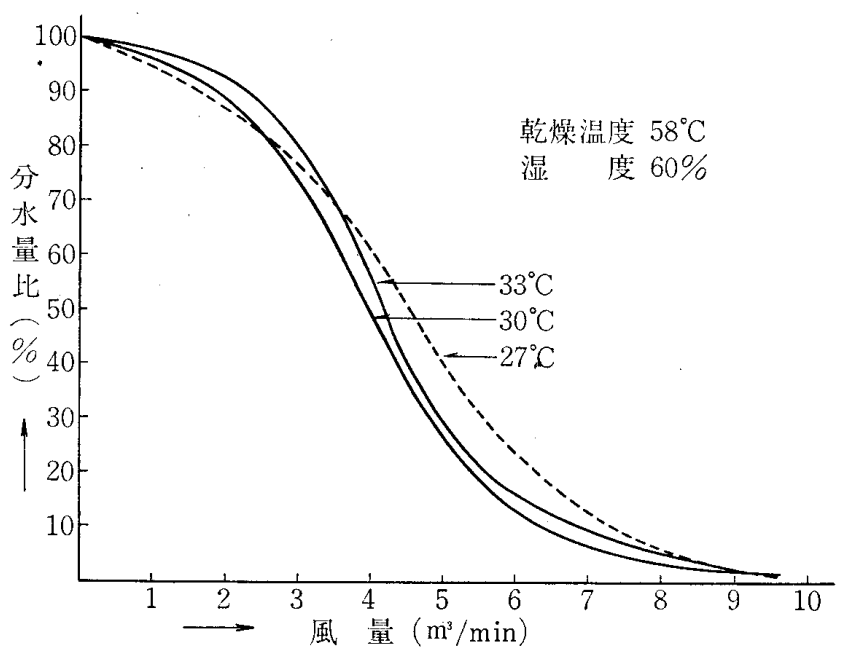

図 7 風量と水洗温度及び乾燥

各サイズフィルムと風量による乾燥（図 8, 8'，表 5 ） 同一条件下における乾燥では大型サイズのフィルム程 風量が多く必要とされるが，なおこれは湿度にも大きく 影響される．実験では湿度 $75 \%$ 80\%, 水洗温度 $32^{\circ} \mathrm{C}$, 定 着温度 $32^{\circ} \mathrm{C}$, 乾燥温度 $56^{\circ} \mathrm{C} \sim 58^{\circ} \mathrm{C}$, 以上の条件下で行な った. フィルムサイズの大となるにしたがって風量む大 となってきている，六切フィルムと半切および大角フィ 
ルムでは約 2 倍の風量差があった.すなわち六切では風

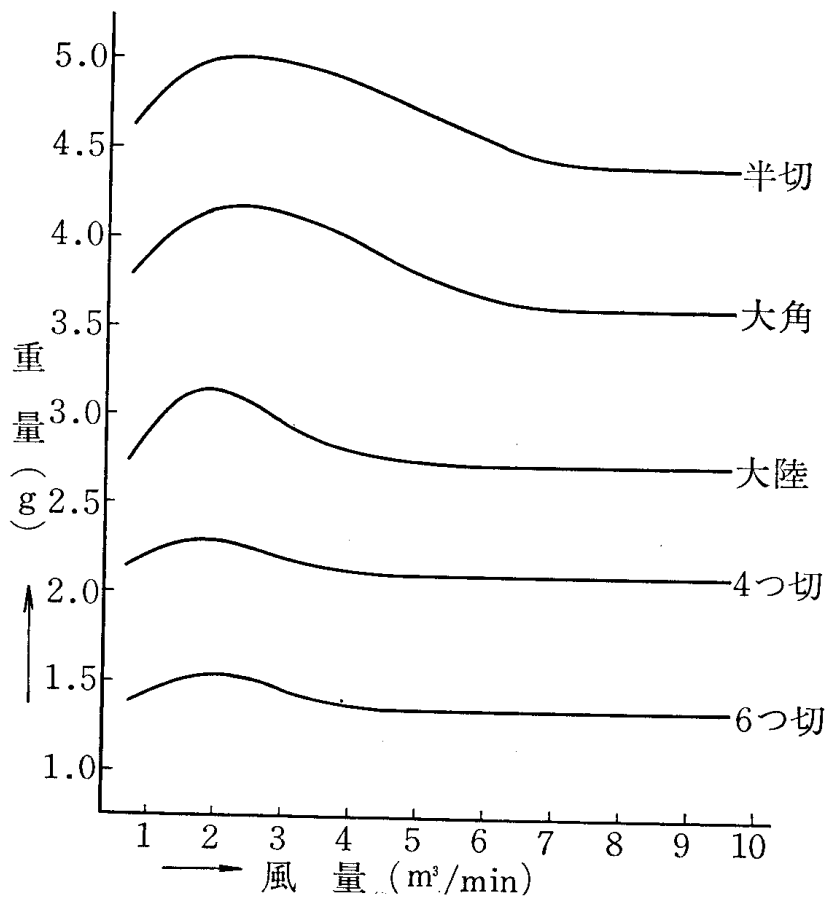

図 8 各サイズフィルムと風量による乾燥

風量不足心依了倝璘む的

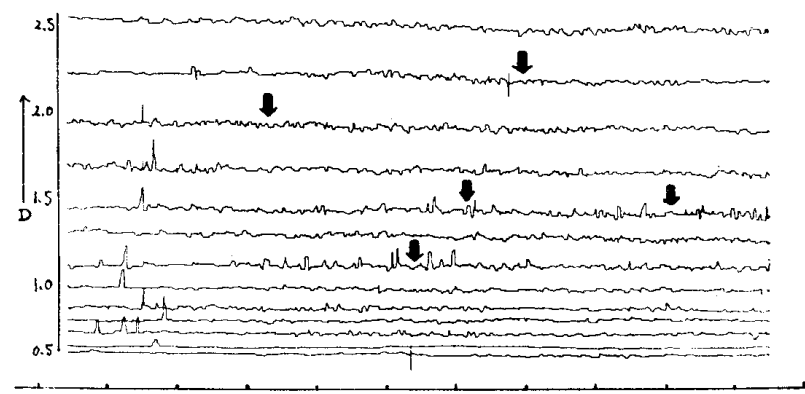

図 $8^{\prime}$

表 5 各サイズフィルムと風量による乾燥

\begin{tabular}{|c|c|c|c|c|c|}
\hline 風量 & 半 切 & 大 角 & 大 陸 & 4ツ切 & 6 ツ切 \\
\hline 0 & 51.0 & 42.4 & 32.0 & 22.7 & 15.2 \\
\hline 1 & 47.5 & 38.5 & 28.0 & 22.0 & 14.0 \\
\hline 2 & 50.0 & 41.5 & 31.5 & 23.0 & 15.5 \\
\hline 3 & 50.0 & 41.5 & 29.5 & 22.0 & 14.5 \\
\hline 4 & 49.0 & 40.0 & 28.0 & 21.5 & 13.5 \\
\hline 5 & 47.0 & 38.0 & 27.5 & 21.0 & 13.0 \\
\hline 6 & 45.0 & 36.0 & 27.0 & 21.0 & 13.0 \\
\hline 7 & 44.0 & 36.0 & 27.0 & 21.0 & 13.0 \\
\hline 8 & 44.0 & 36.0 & 27.0 & 21.0 & 13.0 \\
\hline 9 & 44.0 & 36.0 & 27.0 & 21.0 & 13.0 \\
\hline
\end{tabular}

量 $4.5 \mathrm{~m}^{3} / \mathrm{min}$ で乾燥の状態になり半切，大角では同一 条件下です $7 \mathrm{~m}^{3} / \mathrm{min} \sim 8 \mathrm{~m}^{3} / \mathrm{min}$ と大さく違っている. また大角, 大陸, 四切の各フィルムでは乾燥汇要する風 量差は大体 $1 \mathrm{~m}^{3} / \mathrm{min} \sim 1.5 \mathrm{~m}^{3} / \mathrm{min}$ の差であった。

温度と重量の関係（図9，表 6)

フィルムの乾燥はその乾燥温度によって乾燥状態力゙違 ってくるととはいうまでもないが以下の実験によってて の実態を調查した.

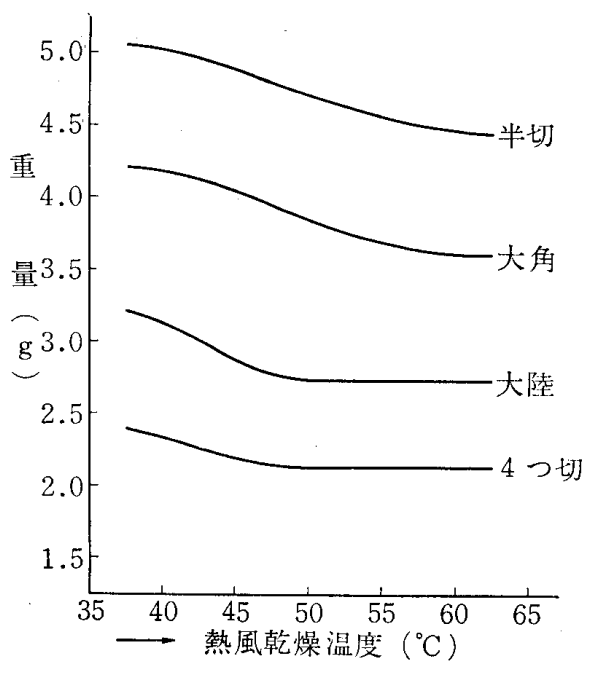

図 9 温度と重量の関係

表 6 温度と重 量

\begin{tabular}{c|c|c|c|c}
\hline \hline フィルム & 半切 & 大角 & 大 陸 & 4 風温度 \\
\hline スクイズローラ迄 & 50.5 & 42.0 & 32.0 & 24.0 \\
$40^{\circ} \mathrm{C}$ & 51.0 & 41.5 & 31.2 & 23.0 \\
$45 "$ & 49.0 & 40.2 & 28.5 & 22.0 \\
$50 "$ & 47.0 & 37.7 & 27.0 & 21.3 \\
$55 "$ & 46.2 & 36.5 & 27.0 & 21.3 \\
$60 "$ & 45.0 & 36.0 & 27.0 & 21.3 \\
$62 \sim 65 ”$ & 44.2 & 36.0 & 27.0 & 21.3 \\
\hline
\end{tabular}

これは湿度75\%〜80\%の状況下で各サイズフィルムす なわち半切〜四ッ切までのフィルム各 1 枚を温度を変化 させてこれ等の点を検討した.

図および表に示すどとく四ッ切および大陸では50Cで 乾燥されたが，大角では $60^{\circ} \mathrm{C}$ 付近で乾燥状態を示し，半 切はそれよりも高く $62^{\circ} \mathrm{C}$ 近くで乾燥を示している．との ととは大型フィルム程高い温度が要求され, 大型フィル ムによる連続処理のときは乾燥室内の水蒸気湿度の影響 あ当然考えられる.したがって乾燥に関しては湿度と温 度が大きく考えられる問題である。なおての実験は各フ イルム 1 枚の場合で検討したのである.

大角フィルム 1 枚〜 60枚連続処理時における含水量比 


\section{亡熱風温度の関係（図10，表 7)}

湿度と乾燥は密接な関係がある。筆者等はこの問題を 検討するため本県高湿度季節である 5 月〜 6 月下旬にか けて実験を試みた。

乾燥状態は含水比で求め，なおとの時の湿度は85\% 90\%であった。

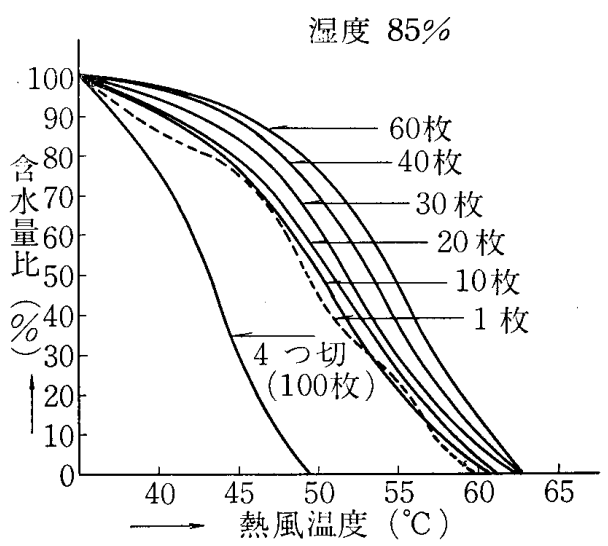

図10大角フィルム1枚〜60枚連続処理時における含水 量比亡熱風温度の関係

表 7 大角フィルム 1 枚〜 60枚連続処理時に 抢ける含水量比と熱風温度と関係

\begin{tabular}{c|c|c|c|c|c}
\hline & 40 & 45 & 50 & 55 & 60 \\
\hline 4 ツ切 & 76 & 30 & 0 & 0 & 0 \\
$(100$ 枚 $)$ & 76 & 75 & 44 & 23 & 0 \\
1 & 86 & 50 & 20 & 2 \\
10 & 89 & 77 & 50 \\
20 & 91 & 79 & 55 & 25 & 3 \\
30 & 94 & 84 & 61 & 29 & 7 \\
40 & 97 & 88 & 70 & 37 & 10 \\
60 & 97 & 90 & 76 & 47 & 14 \\
\hline
\end{tabular}

図に示すごとく大角 1 枚から10枚までは乾燥は大きな 差はなく，20枚から徐々にその差が現われてきている. すなわち 1 枚と60枚との差は $7^{\circ} \mathrm{C}$ 近くの温度差が認めら れた。

しかし四ッ切 100 枚で処理の場合 $50^{\circ} \mathrm{C}$ 近くで乾燥され, 大角連続処理 60 枚と四ッ切 100 では実に $10^{\circ} \mathrm{C}$ 以上の開き が生じた。

以上のととを考えるに四ッ切以下の処理のときは枚数 が增えてす大差なく同一条件で乾燥されるが，高湿度下 における大型サイズフィルムの連続処理の場合には，枚 数増加によっては，ある程度の乾燥温度上昇を考慮に入 れなければならないと考える。

四ッ切フィルムと大角フィルム連続処理における含水 量比と湿度および枚数の関係（図11）

これは最覀の状態におけるフィルム連続処理した時の

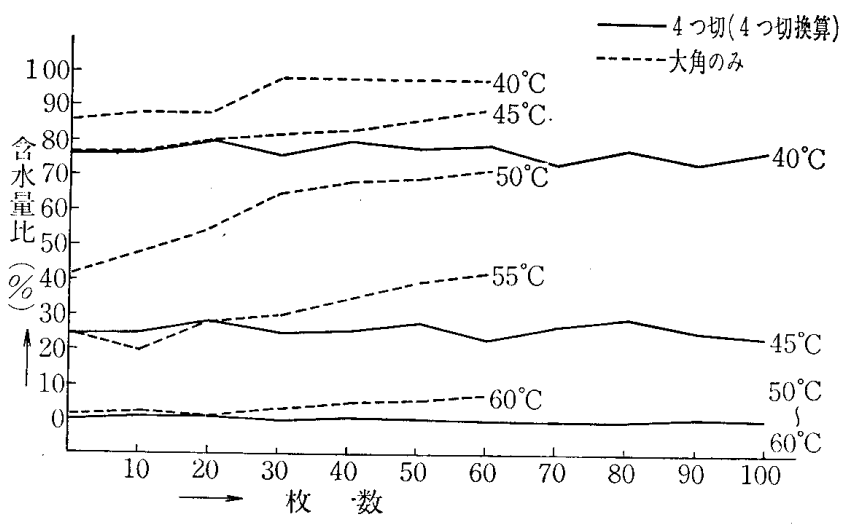

図11四切フィルムと大角フィルム連続処理に打的る含 水量比と温度及び枚数

乾燥状態である．すなわち湿度 $90 \%$ を示した時の実験成 績である.

図で示すどとく温度 $40^{\circ} \mathrm{C}$ おび $45^{\circ} \mathrm{C}$ ではほとんど乾燥

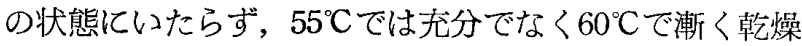
に近い状態を示した. しかし枚数增加によって次第に含 水比む高くなっている.

四ッ切フィルムの場合は枚数差に関係なくそれぞれの 含水量は一定に近い值をたどっている.

以上の成績を考えると大型フィルムの連続処理には湿 度が高い乾燥に影響され易い。また乾燥温度にも影響 する。

また処理枚数が増加する程との乾燥状態が悪くなると 考える.

\section{湿度変化と乾燥（図12）}

乾燥と湿度は非常に関係が深いが，本奏験中にあ湿度 が大さく左右された.フィルムの乾燥にはその影響が大 であった.

当北陸地方は全国有数の湿度の高いことで有名であり とくに梅雨前線の停滞する 5 月〜 6 月下旬頃には実に平 均湿度は $80 \%$ 以上越す日は多いのである，そこで湿度と

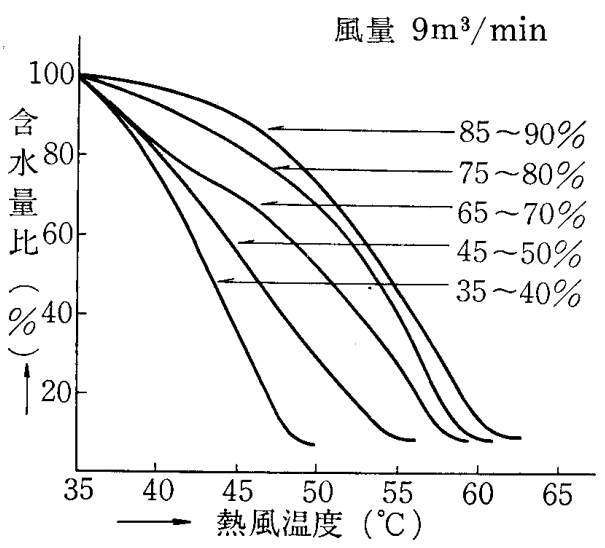

図12 湿度変化と乾燥 
乾燥の問題を取りあげてフィルムの乾燥状態を観察し た。

図に示すごとく大角60枚連続処理した場合であるが風 量 $9 \mathrm{~m}^{3} / \mathrm{min}$ で以下同一条件下の実験成績である. 同一 乾燥温度であ湿度差によってその乾燥には非常な差が見 られる.

湿度 $35 \%$ ～40\%では乾燥湿度が50 50 以下で乾燥し， 45 $\%$ \% $50 \%$ で50 $0^{\circ} \mathrm{C}, 65 \sim 70 \%$ では $57^{\circ} \mathrm{C} ， 80 \%$ \% $9 \%$ で実に $60^{\circ} \mathrm{C}$ 以上の温度が必要とされた。

以上のととから湿度の高い地方では自動現像装置の設 置には設置場所の除湿およびその設置場所の選定等に対 して考慮が必要かと思われる。なおこの問題に関しては 更に追試検討を加える必要があると思われる。

\section{む す び}

水洗温度の上昇によって水洗効㻭がよくなるが，また 一方では水洗中にも八イポ量が多くなってくる. この現 象はフィルムが大型になる程，またその処理枚数が連続 的に増加する程しの傾向が強くなってくる.とれがスク イズローラ, および乾燥ローラの一部を励染してフィル ムの仕上がりに障害をきたすすのと思われる.

大型フィルムによる連続処理には水洗流水量はなるべ く多く，指定されている流水量では不充分であると考 える. 低温水洗では水の温度が低いため水洗効率が鳃く 乾燥仕がりに障害を認めた。

以上のととにより 3 分30秒処理の自動現像装置, 水洗 処理に関しては連続大型フィルムでは流水量を $15 ! / \mathrm{min}$ 以下では適当量といえず，水の温度は $30 \mathrm{Cから} 32 \mathrm{C}$ が適 当と考える. $30^{\circ} \mathrm{C}$ 以下では仕上がり時には支障を来たす 恐れがある。

乾燥時の風量であるが, 大型フィルム程, また連続処 理する程, 風量が多く要求され, 実験成績では最も少な くても $6 \mathrm{~m}^{3} / \mathrm{min}$ が必要であり，連続処理 100 枚以上の ときは $9 \mathrm{~m}^{3} / \mathrm{min}$ であ充分とはいえなかった。

次に乾燥温度と湿度であるが，実験成績では湿度差に よって乾燥温度が非常に影響されこれがフィルムの仕上 がり状態を大きく左右した. また湿度50\%以下のときは 乾燥温度を必要以上に上昇してもその効果は少ないと思 われる.

以上のととにより大型フィルムの連続処理に対しては 水洗流水機構および乾燥機構等にさらに検討の余地があ ると考える.

おわりに際して松田技師長をはじめとし山本技師，島 田技師，松平技師に絶大なる御教示を頂いたととに対し
深くお礼申しあげます。

1) 島津評論 40 年 12 月号

2) 島津評論 1964年 Vol 21, 4

3) 島津評論 44 年 3 月号

4）写真工業 感光シリーズ 62

5）日本医学放射線学会雑誌 1963年 22.984

6）第25回日本放射線技術学会抄録集

7) Medical, Radiography No. 19, 67. (Kodak)

8) Medical Radiography No. 2, 56. (Kodak)

9）日本放射線技術学会雑誌 24 巻 22 号

10）富士Xレイ研究 1967-No. 77.

11)さくらXレイ写真研究 68 Vol. 19, No. 1.

12) 科学写真便覽 上巻

13）日本放射線技術学会雑誌 24 巻 4 号

\section{質 疑 討 論}

\section{金田}

只今の南君のお話の発言者として 名古屋大学 伊藤 謙助君に打願しします。

伊藤 (愛知)

只今の水洗の件に関しての発表に対してさくらの I 型 ですとメーカ一指示に毎分 $13 l$ にするという指示がで ている.今回の発表では毎分 $15 l$ というデータがでたと いうととは結局大角サイズを連続的に流した場合にメー カー指示以上にしないと駄目だと抨聴していた．僕のと ころは自現機 3 台ありますが多くなると 1 台の自現機を 連続撮影専用に使うと,乙ういう問題がでてくる. その時 水量問題で自分のところの自現機で数10枚大角フィルム を流す場合にメ一カー指示量でどうかということは，自 分のところで検査しなければ，ならない．私のところは 矢張り水洗水量を2.4.6.8各 $l$ といろいろ変えてその時 の残留ハイポを検討している．乙れは全国的にあてはま る問題であってその施設の水質とか水圧の変化とか，い ろいろの問題がでてくるので各施設において水量, 温度 変化等によるデータをとっておくととが必要と考えます。

\section{金田}

水量の問題について第一席の泉君何かありませんか。

\section{泉}

水量の問題しれは, メ一カー指定は一般的に12 13l/ 分と指定されているが，只今の発表は連続の場合に $15 l$ 以上流しておられる.たしかにてれは，その通りと思う が今度は地域的なしとで, 寒冷地におきまして果して, 15〜16l の温水を長時間温度の変化をそれほど多くとら 
ないで連続に流すことは難しい問題ではないかと考えま す.もう一つ，15l 以上の温水を 30 度あるいは 33 度とい う水温で流すと, さき程の私の発表にもふれるが現在自 現機はほとんどのあのが水洗水そのむのが現像液温を上 まわりますと現像液温が上がる，パコでは間題ありませ んがその他の装置は水温が大きいと理論的には，うなず ける点すあるが現在の機構では難しいのではないか. こ れについては，メーカーの検討をもとにされてモデルチ ェンジし，楽にできる開発をのぞみます。

\section{金田}

なお，小西六の若林康夫さんに補充液の問題と関連し て只今の問題について何か.

\section{若林}

只今の問題なかなかいるいると難しい問題ですが，水 量の問題は一応只今の話ですと, 水洗水中のハイポ量と いっておられたが，私ども問題に致しますのはフィルム の中の残留ハイポ量が問題となって参りまず. 只今の水 洗水中の残留八イポ量とフィルム中の残留ハイポの関係 がでておりますと非常に参考になったと思いますが，私 共の実験では $13 \mathrm{l} / \mathrm{min}$ で充分というととになっていま すが. それから補允量の問題ですが定着む先程でていま したが，現像法は先程お答えされたが仕上げましたフィ ルム濃度あるいは黒化された面積によって現像液消費量
が変って参ります．したがって消費される補充量という のは,あくまで黒化された濃度であるとか, 面積てれによ って現像液の消費量が変って参りますので, それに応じ て若干のコントロールが必要じゃないかと思います. 定 着におきましても，よけいに現像されていると残りまし たハロゲン化銀が少なくなって参りますので夭張り黒化 濃度によって定着液補允む若干変ってくるわけでありま す.というわけでメ一カ一指定補充量は，あくまで基準

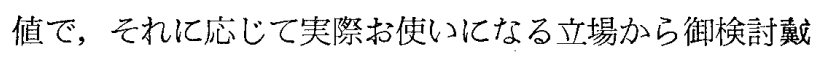
くのが一番良いではないかと思っております。

\section{金田}

今のお話の中に含めていいと思うんですが空気の湿度 というもの, 矢張り乾燥に影響すると思うがその点につ いて，若林さんどうでしょう.

\section{若林}

申しおくれましたが空気の湿度が高くなると乾燥が悪 くなる，乾燥温度を上げなけれげというととになる。

自現機の中で循環している空気は部屋の空気と無関係 でなく, 部屋の空気む立分換気するとと, そうすると自 現機内の混度も下って参りますので両方の面から御注意 戴きたい.

\section{金田}

では，第四席の安威徹君願いましょう。 